\title{
literary matter
}

\section{New from Chicago}

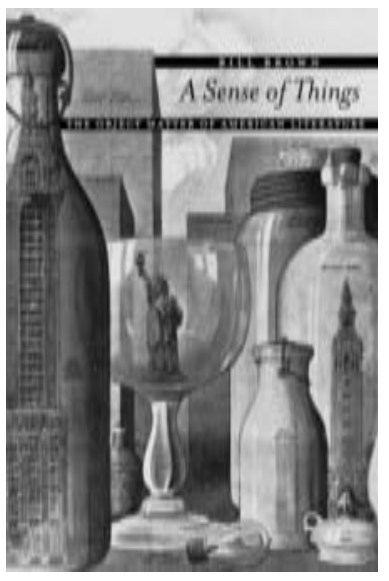

\section{A Sense of Things}

The Object Matter of American Literature

\section{Bill Brown}

"A daringly original study of 'things' in American art and thought at the turn of the last century, $A$ Sense of Things opens vistas of speculation that will inspire American cultural studies for many years to come. The literary analyses at the center of the book-works by Mark Twain, Frank Norris, Sarah Orne Jewett, and Henry James_-are enhanced and brilliantly illuminated by an extraordinary array of insights from philosophy, anthropology, visual art, social history, and material culture. In this powerful, courageous, and absolutely compelling work, Bill Brown delivers a stunning new interpretation of the passage of American culture, in the broadest sense, into the complex modernity of the early twentieth century." -Alan Trachtenberg, Yale University Cloth $\$ 32.00$

\section{Black, White, and in Color}

Essays on American Literature and Culture

\section{Hortense J. Spillers}

"Hortense Spillers has been one of the central shaping forces in African American feminist theory and criticism for the past two decades. Each of us in the fieldboth colleagues and studentshave profited greatly from her bold, insightful, and original interpretations of what it means to be black and a woman and dare to speak or write. Spillers's voice has played such a fundamental part in contemporary critical discourse that one can hardly believe that her work has not been collected before. But Black, White, and in Color was well worth the wait. Its publication only reaffirms Spillers's pivotal role as a major thinker in African American letters and literary theory." -Henry Louis Gates Jr., Harvard University

Paper $\$ 27.50$

\section{Barbaric Intercourse}

Caricature and the Culture of Conduct, 1841-1936

\section{Martha Banta}

"Stunningly erudite and thorough, richly informative and insightful, broadly contextualized and utterly fascinating. Martha Banta is one of the most impressive and accomplished scholars in the field, and all of her work - this book no exception-justifies the reputation. This book will be essential reading for scholars of American literature and culture."-Priscilla Wald,

Duke University

Paper $\$ 30.00$

\section{Literature after Feminism Rita Felski}

"Gives feminist criticism a public voice. Disproving its critical caricatures while dealing squarely with its weaknesses, Felski explains what feminist criticism is all about. This timely and useful book carries out an important political and intellectual task, and is an absolute pleasure to read."-Toril Moi, Duke University

Paper $\$ 16.00$

\section{The Mourner's Song}

War and Remembrance from the Iliad to Vietnam

\section{James Tatum}

"The classicist James Tatum has taken two numinous texts, Homer's Iliad and Maya Lin's Vietnam Memorial, and studied them in their various dimensions along with other voices like Robert Lowell and General Grant, creating something new out of man's obsession with war and memory that roves backlike the rose-through so many wild centuries to our origins and the titanic wrath of Achilles before the walls of Troy."

-Gore Vidal

Cloth $\$ 32.00$ 


\section{The Bedford Anthology of}

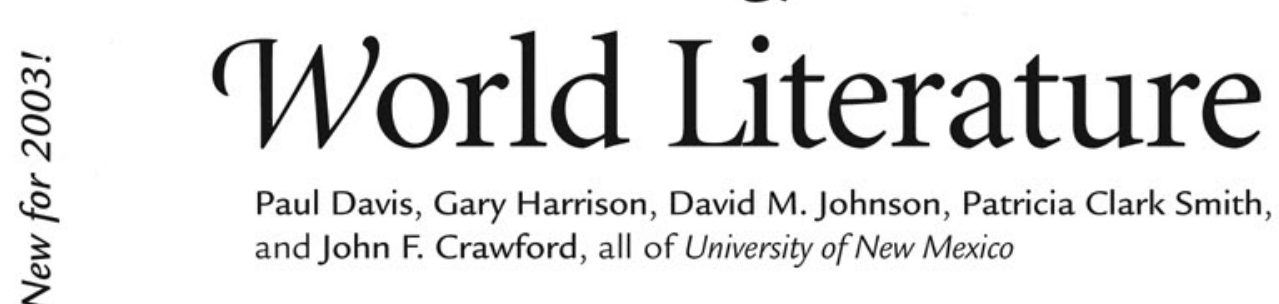

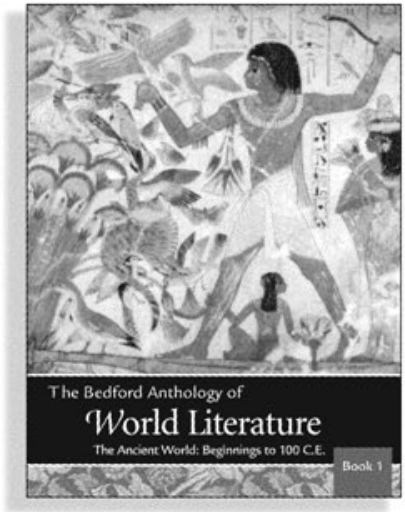

1650-The Present Package B - Paperbound

Book 4 (The Eighteenth Century, 1650-1800) Book 5 (The Nineteenth Century, 1800-1900) Book 6 (The Twentieth Century, 1900-The Present)

\section{Available now!}

This new anthology contains the tools students need to read, comprehend, and enjoy the best the world has to offer - including thematic groupings of literature from all over the world, social and historical contexts, comparative timelines, abundant maps, hundreds of images, and much more. It's the first anthology to acknowledge the wide geographical and chronological range of material students are being asked to cover in the world literature course - and then do something about it.

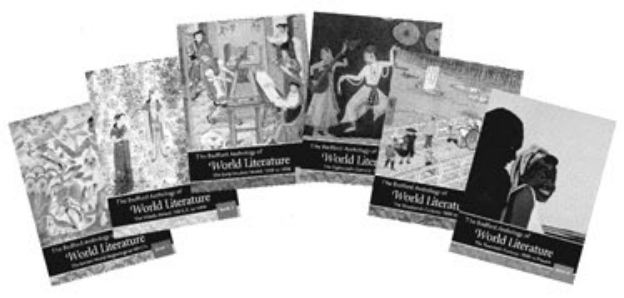

\section{Earliest Recorded Literatures-1650} Package A - Paperbound

Book 1 (The Ancient World, Beginnings -100 C.E.)

Book 2 (The Middle Period, 100-1450)

Book 3 (The Modern World, 1450-1650)

Available July 2003

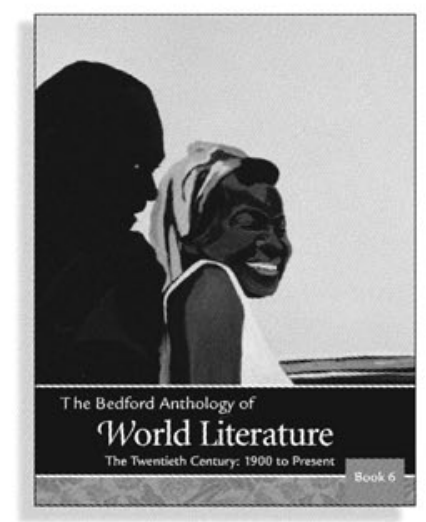

- Six paperback books - available in two packages or as individual texts - correspond to the six periods most commonly taught. Each book features a striking twocolor design that showcases the literature, highlights pedagogical features, and sets off the many maps and illustrations to best effect.

- Superb collection of complete longer works, plays, prose, and poems represents the best literature of all time available in English or English translations from around the globe. Unique "In the World" clusters emphasize social and historical contexts.

- Practical and accessible editorial apparatus helps students understand what they read and allows them to place literature in a larger context. Resources inside the anthology include Time and Place boxes, Bibliographies, Connections questions, and a Glossary of Literary and Historical Terms. An extensive Instructor's Manual and a rich Web site, World Literature Online, provide additional support. 